\title{
メッシュデータを用いた札幌・東京・大阪圏における 土地利用変化と地形との関係分析
}

\section{Mesh Data Analysis on Land Use Change and Its Correlation with Topographic Condition in Sapporo, Tokyo and Osaka Metropolitan Areas}

\author{
大原 譽丈*，山下 亜紀郎"* \\ Yoshitomo OHARA* and Akio YAMASHITA**
}

キーワード : メッシュデータ, 土地利用変化, 地形条件, 都市圈

Key words : mesh data, land use change, topographic condition, metropolitan area

I 、はじめに

\section{1. 研究目的}

土地利用は人為的, 自然的な様々な要因に影響 され時代とともに変化するものであり, その変遷 を追うことは，都市の発展やそれに伴う自然環境 の変化を把握する上で重要なことである。

既往の土地利用研究を概観すると, 日本では, 国土交通省が中心となって，土地利用に関するデ ジタルメッシュデータが整備・公開されており, 比較的容易に土地利用分析を行うことが可能であ る（杉森·大森，1996;山下，2004など）。しかし, このデータは 1970 年代以降を対象としたもので あり，それより過去のデー夕はない。

それに対して, 旧版地形図を用いて過去の土地 利用を復原し, 現在との比較分析を行った研究と してはまず，氷見山幸夫らによる一連の研究が 挙げられる（水見山・綿木, 1990 ; 水見山ほか, 1991 ; 水見山 ·太田, 1993 ; 水見山・本松, 1994 など）。この研究では明治・大正期および昭和中 期 (1950 年代) の 5 万分の 1 地形図から, 日本 全国 $2 \mathrm{~km}$ メッシュ単位の土地利用データを作成
している。また, 王尾ほか（2006）や王尾（2008） では, 北関東の那珂川, 霞ヶ浦, 鬼怒川, 小貝 川の 4 流域を対象に, 明治期の 5 万分の 1 地形図 から $250 \mathrm{~m}$ メッシュの土地利用データを作成し, 標高や河川からの距離等の自然的条件との関係解 析を行っている。池見ほか (2008) は, 1900 年 代と 1950 年代の 5 万分の 1 地形図から, 福岡県 全域の $100 \mathrm{~m}$ メッシュ土地利用データを作成し, 時系列的変化を分析している。

これらのように土地利用データを GIS で利用 可能なデジタルメッシュデータとして整備するこ との利点は, ほかのデジタルデータと重ね合わせ てその空間的相互関係を解析できるところにあ る。しかし，先述の王尾らの研究のように，ある 程度長い時間スケールを対象に土地利用の変遷を 明らかにし，ほかの地域条件との空間関係を解析 したものはほとんどない。

そこで本研究では, 札幌・東京・大阪の 3 都市 圈の 3 時期を対象に土地利用メッシュデータを独 自に作成し，土地利用の空間的变遷を明らかにす るとともに，地形的条件として標高と傾斜を取り

\footnotetext{
*財団法人北海道農業近代化技術研究センター／Foundation the Hokkaido Agricultural Modernization Technology Research Center, Japan

***筑波大学大学院生命環境科学研究科 /Graduate School of Life and Environmental Sciences, University of Tsukuba, Japan
} 
上げ,それらと土地利用変化との関係性を分析し， 都市圈間の差異について考察することを目的とす る。

\section{2. 研究方法}

分析対象地域は, 日本の 2 大都市圈である東京, 大阪に加え, それらとは歴史的, 自然的背景が異 なる独自性を有する北海道の札幌を合わせた 3 都 市圈とした。時間スケールとしては, 既往研究の 対象年次や基図としての旧版地形図の整備状況な どを勘案し, 1930 年頃, 1970 年頃, 2000 年頃の 3 時期とした。ただし札幌圈については 2000 年 頃以降の 5 万分の 1 地形図が未整備の範囲がある ため, 1990 年頃とした。

本研究で用いる土地利用メッシュデータのうち 東京圈と大阪圈については, 山下ほか (2009) や Yamashita（2011）で作成されたものである。こ れらの研究では, 3 時期の土地利用分布とその変 化の概要が述べられているが, 本研究では札幌圈 を加えてより詳細な解析を行い，3都市圈を比較 する。札幌圈のデー夕は, 東京圈, 大阪圈と同様 の作成基準と方法によって, 本研究で独自に作成 したものである。

データの詳細な作成基準と方法については上記 の先行研究で述べられているので, ここではそれ を要約して簡潔に述べる。まず，分析対象地域の 3 時期の国土地理院発行 5 万分の 1 地形図を収集 し, スキャナーで画像データ化し, 幾何補正した。 次に別途作成した $500 \mathrm{~m}$ メッシュを GIS 上で重 ね合わせ, 各メッシュの中で最も卓越している土 地利用を目視判読し, カテゴリーデータとして入 カした。カテゴリー (土地利用項目) としては「森 林」, 「草地・荒地」,「田」,「その他の農地」,「工 業用地」,「宅地」, 「水域·湿地」,「その他」,「海」 の9 項目を設定した。

このように作成された土地利用メッシュデータ に, 国土地理院の基盤地図情報の数值標高モデル (DEM） $10 \mathrm{~m}$ メッシュを重ね合わせ，土地利用 データの $500 \mathrm{~m}$ メッシごとに平均標高と平均 傾斜を算出することによって, 本研究では, 地形 を標高と傾斜の 2 つの指標で代表させ， 3 都市圈 の土地利用変化と地形との関係を分析した。

\section{II. 研究対象地域の概要}

本研究が対象とする都市圈とは, 山下ほか (2008，2009）にならい, 各都市の都心からみて 土地利用としての市街地が連担している範囲を包 含するような, それよりやや広い範囲とした。な お本研究では以下に示す通り地形図の図幅で形式 的に対象地域を区切っているが, 本研究は都市圈 を対象に, 土地利用変化のなかでも特に農地化や 都市化といった土地開発の空間的拡大過程と地形 特性との関係を比較分析することに主眼を置いて おり, そのような現象が起こった範囲と開発前線 としてのその周辺部を包含している限り, 本研究 の趣旨を達成する上で問題ないと判断される。

\section{1 . 札幌圏}

分析対象範囲は国土地理院発行 5 万分の 1 地形 図で『小樽東部』『石狩』『銭函』『札幌』『江別』『定 山渓』『石山』『恵庭』『歳』の9 図幅分とした (本 研究ではこの範囲を札幌圈とよぶ)。

札幌圈は札幌市の大部分および, 江別市, 北広 島市, 恵庭市の全域, 石狩市, 千歳市の一部など を含む。北海道最大の一級河川である石狩川の中 流・河口付近に広がる石狩平野に位置している。 石狩平野は東側を夕張山地，南西側を余市岳およ び恵庭岳，北側を増毛山地などに囲まれ，東部に 日本最大の炭田である石狩炭田, 西部に札幌市が 位置している。また，石狩川が蛇行する中央部 に低湿な泥炭地が形成されており（小疇ほか編， 1994），低地が高い割合を占めている。

札幌圈の標高データからは, 概ね東部が低標高・ 緩傾斜地域であり, 南西部が高標高・急傾斜地域 であることがわかる。標高值の最大は $1,481.1 \mathrm{~m}$, 平均は $222.9 \mathrm{~m}$ であり, 標高 $100 \mathrm{~m}$ 以下の地域 は全体の $59.3 \%$ である。また, 傾斜角は最大 77.3 度, 平均 8.6 度であり, 傾斜 5 度以下の地域が全 体の $52.0 \%$ を占める。

\section{2. 東京圏}

分析対象範囲は国土地理院発行 5 万分の 1 地形 図の図幅で『三崎』『田原』『平塚』『横須賀』『富津』 『大多喜』『秦野』『藤沢』『横浜』『木更津』『上野 原』八王子』東京西南部』『東京東南部』『五日市』 『青梅』『東京西北部』『東京東北部』『秩父』『川越』 
『大宮』『野田』『姉崎』『千葉』『佐倉』『龍ヶ崎』『寄 居』『熊谷』『巣鴨』『水海道』『高崎』『深谷』『古 河』『小山』土浦』『真壁』の 36 図幅分とした（本 研究ではこの範囲を東京圈とよぶ)。

東京圏は, 日本で最大の平野である関東平野を ほぼ包含し, 関東地方の 1 都 6 県にまたがる範囲 である。関東平野は西側を関東山地，北側を阿武 隈・八溝・足尾・三国諸山地, 東側と南側を太 平洋に囲まれている。また, 関東平野には台地と 丘陵が多く形成されており（中村ほか編，1994）, 埼玉県の大宮台地や比企丘陵, 東京都の武蔵野台 地や多摩丘陵などがある。

東京圈の標高データからは, 東部に低標高・緩 傾斜地域, 西部に高標高・急傾斜地域が分布して いることがわかる。また，南東部にもわずかでは あるが高標高・急傾斜地域があることがわかる。 標高值の最大は $1,734.7 \mathrm{~m}$, 平均は $136.0 \mathrm{~m}$ であ り, 標高 $100 \mathrm{~m}$ 以下の地域が全体の $71.4 \%$ である。 また, 傾斜角は最大 83.7 度, 平均 8.2 度であり, 傾斜 5 度以下の地域が全体の $63.2 \%$ を占める。

\section{3. 大阪圏}

分析対象範囲は国土地理院発行 5 万分の 1 地形 図の図幅で『尼崎』『岸和田』『五条』『須磨』『大 阪西南部』『大阪東南部』『桜井』『神戸』『大阪西 北部』『大阪東北部』『奈良』『三田』『広根』『京 都西南部』『京都東南部』『京都西北部』『京都東 北部』の 17 図幅分とした（本研究ではこの範囲 を大阪圏とよぶ)。

大阪圈は，大阪府の大部分を含む近畿地方の 6 府県におよぶ範囲である。大阪圈には石狩平野や 関東平野のような大平野が存在せず，小規模な平 野・盆地と山地が交錯した複雑な地形条件となっ ている。大阪圈の中心部に位置する大阪平野は東 側を生駒山地, 西側を大阪湾, 南側を和泉山地, 北側を北摂山地に囲まれている。また，各府県境 が山地であることが多いため, 各府県は地形的に 分断されている。そのため, 各府県庁が所在する 中心都市はそれぞれの府県の中心的な平野・盆地 に立地することが多いが, 兵庫県ではやや異なっ ており, 播州平野に立地する姫路ではなく, 大阪 平野と隣接する六甲山地南麓に県都である神戸が ある（金田・石川編，2006）。
大阪圏の標高データからは，中央部に低標高 · 緩傾斜地域があり, その周囲を高標高・急傾斜地 域が取り囲んでいることがわかる。標高值の最 大は $1,124.0 \mathrm{~m}$, 平均は $193.1 \mathrm{~m}$ であり, 標高 100 $\mathrm{m}$ 以下の地域は全体の $38.7 \%$ である。また, 傾 斜角は最大 78.2 度, 平均 13.0 度であり, 傾斜 5 度以下の地域が全体の $35.5 \%$ を占める。札幌圈, 東京圈と比べて低標高・緩傾斜地域の割合が低い。

\section{III. 土地利用分布とその变化 \\ 1. 札幌圏}

札幌圈の土地利用メッシュマップ（図 1 ) から, 札幌市の東部に農地, 西部に「森林」が多く分布 していることがわかる。これは 3 時期に共通する ことである。1930年頃から 1970 年頃にかけては， 札幌市周辺の「宅地」の増加と, 南東部に分布し ている「水域・湿地」から「田」への変化が特徽 的である。また, 1970 年頃から 1990 年頃にかけ ては札幌市周辺部で「宅地」がさらに増加してい る。

札幌圈における 3 時期の土地利用割合（図 2) を見てみると,「森林」,「水域・湿地」は一貫し て減少し,「宅地」,「工業用地」は増加している。「草 地・荒地」,「田」は 1930 年頃から 1970 年頃にか
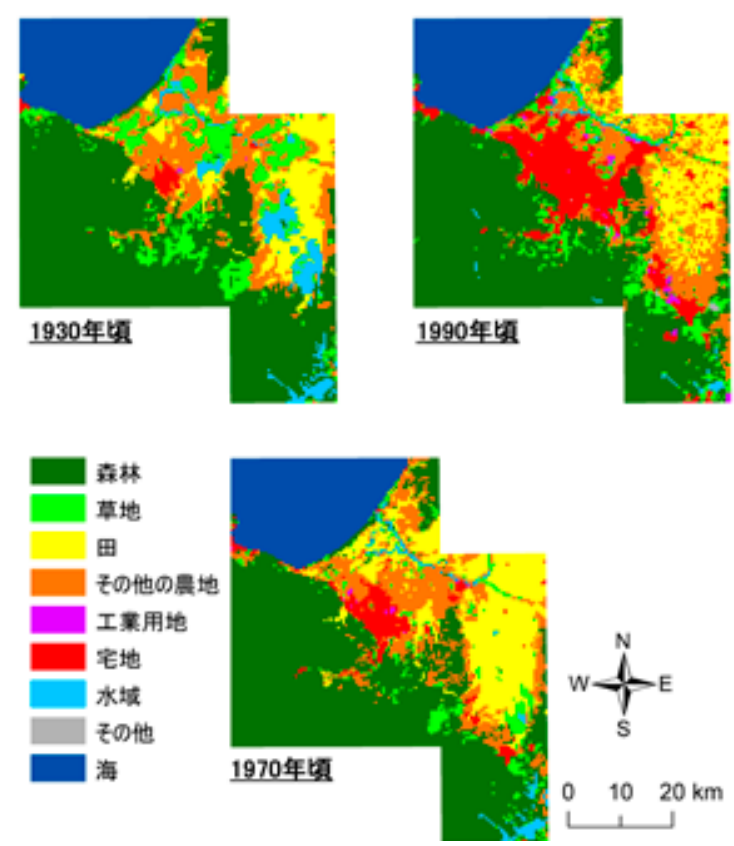

図 1 札幌圈の土地利用分布 


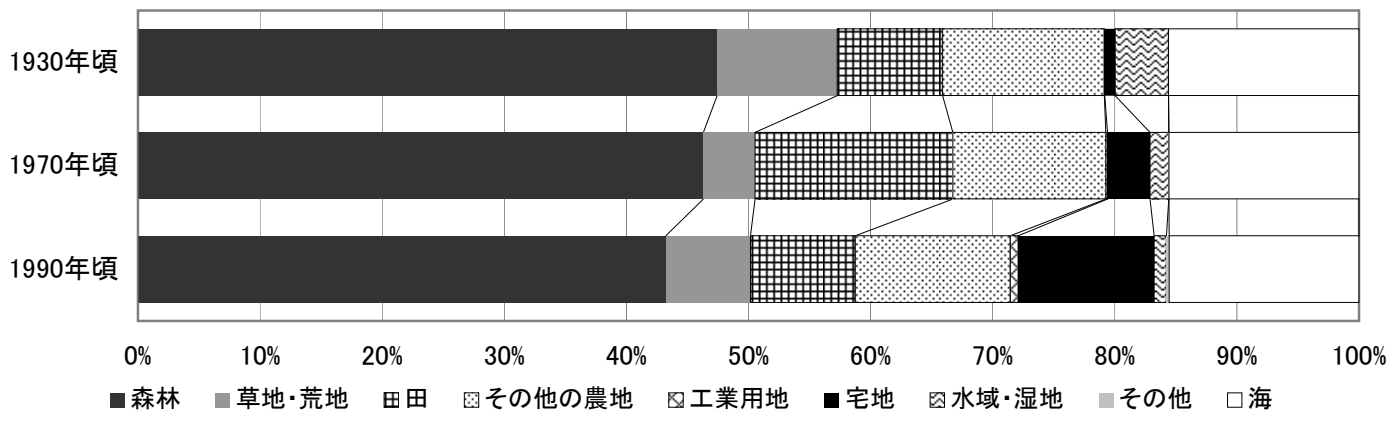

図2 札幌圈における 3 時期の土地利用割合

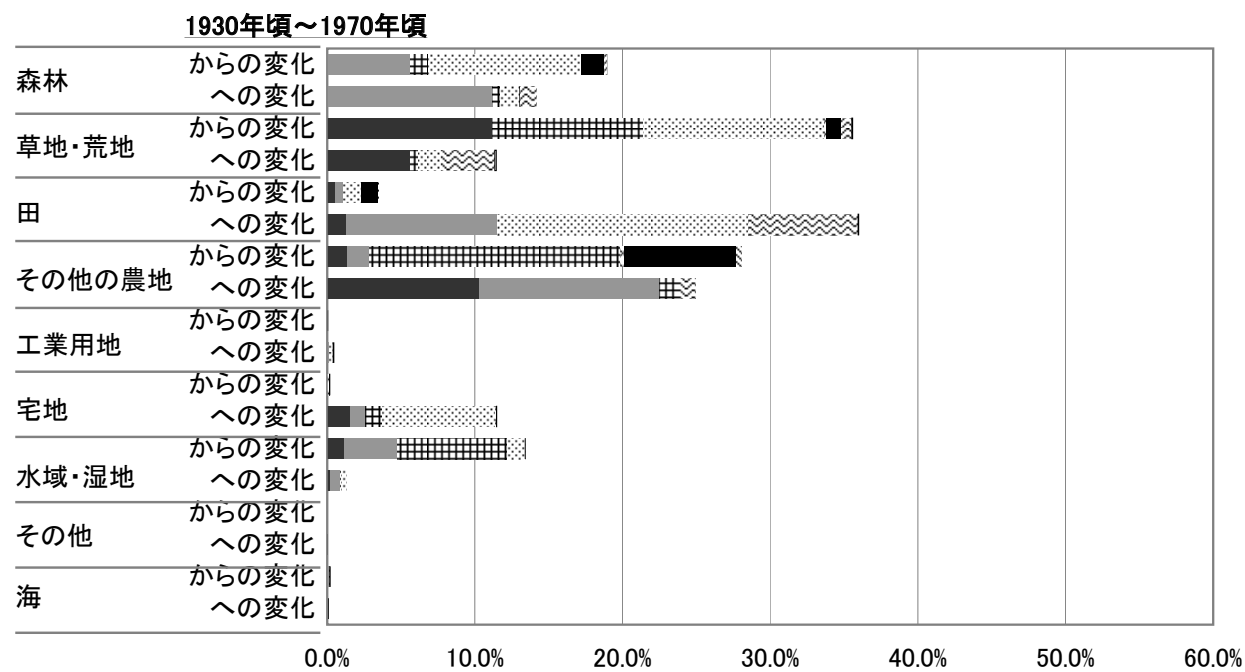

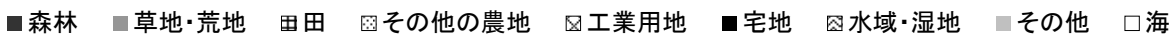

1970年頃〜 1990年頃

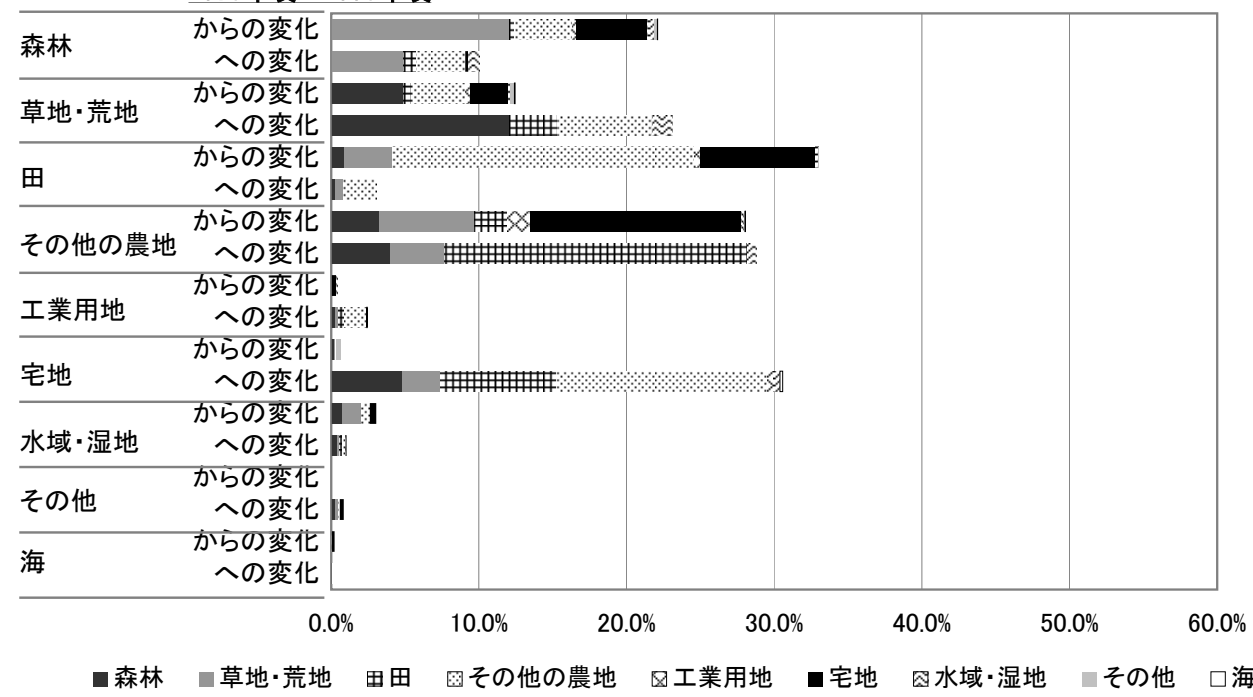

図3 札幌圈における土地利用項目別変化割合

各項目の「からの変化」および「への変化」をそれぞれ合算すると100\%になる。 
けて一旦増加してから 1990 年頃までに減少した。 「その他の農地」は同程度の割合で推移した。

1930 年頃から 1970 年頃では, 全体の 23.3\%（海 を除く）のメッシュで卓越土地利用が変化してい る。この 2 時期間での土地利用項目別変化割合(図 3）を見てみると, 「草地・荒地」からの変化と 「田」への変化が高い割合を示した。「草地・荒地」 からは「田」,「その他の農地」への変化が多く, 「田」への変化は「その他の農地」からの変化が 多かった。「その他の農地」への変化は高い割合 を示したが,「その他の農地」から他の土地利用 への変化の割合と同程度であるため,「その他の 農地」の面積率自体は見かけ上あまり変化してい ない（図 2)。「宅地」は主に「その他の農地」か らの変化であった。また,「水域·湿地」から「田」 や「草地・荒地」への変化も高い割合を示した。

次に, 1970 年頃から 1990 年頃では, 全体の 25.5\%（海を除く）のメッシュで卓越土地利用が 変化している。この 2 時期間での土地利用項目別 変化割合（図 3 ）を見てみると,「田」からの変 化と「宅地」への変化が高い割合を示した。「田」 からは「その他の農地」への変化が多く,「宅地」 へは「その他の農地」からの変化が多かった。また, 「その他の農地」は1930 年頃から 1970 年頃にか けてと同様に高い割合で変化しているが，「その 他の農地」からの変化と,「その他の農地」への 変化が同程度であるため,「その他の農地」の面 積率はあまり変化していないことになる（図 2)。

以上を要約すると, 札幌圈では 1970 年頃まで は畑地の水田化が積極的に行われた一方で, 1970 年頃以降は逆に水田の畑地化が進んでいることが 分かった。宅地化の進展については, まず草地 · 荒地といった自然緑地が水田や畑地といった生産 緑地に転換され, その後それらの生産緑地が宅地 化されるという2 段階の土地利用変化を経てきた ことが分かった。

\section{2. 東京圏}

東京圈の土地利用メッシュマップ (図 4 ) から, 1930 年頃では中央部に位置する都心部より北部 に「田」, 西部に「その他の農地」,「森林」が分 布していることが分かる。1970 年頃, 2000 年頃 では「田」,「その他の農地」が減少し「宅地」の
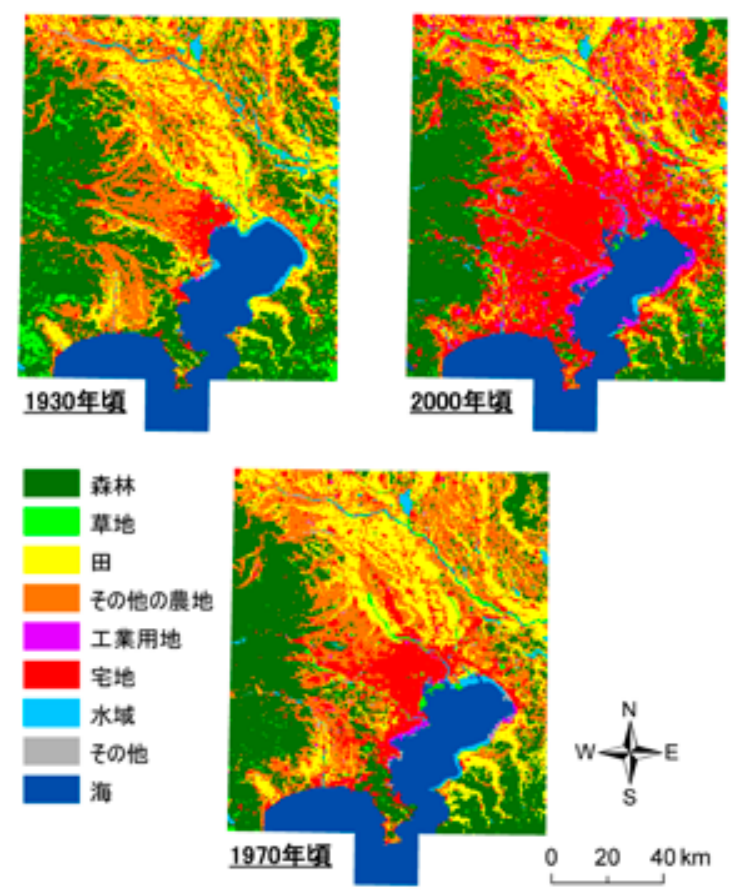

図4 東京圈の土地利用分布

増加がみられたが, 西部の「森林」は 3 時期を通 してあまり変化していない。

東京圈における 3 時期の土地利用割合（図 5 ) を見てみると,「宅地」,「工業用地」は一貫して 増加しているが,「森林」,「水域・湿地」は減少 していた。「草地・荒地」,「田」,「その他の農地」 は 1930 年頃から 1970 年頃にかけて増加したが, 1970 年頃から 2000 年頃にかけては減少した。

1930 年頃から 1970 年頃では, 全体の 28.8\%（海 を除く）のメッシュで卓越土地利用が変化してい る。この 2 時期間での土地利用項目別変化割合 (図 6 ）を見てみると,「森林」からの変化と「その 他の農地」への変化が高い割合を示し, 特に「森林」 から「その他の農地」への変化が高い割合を占め ている。また,「宅地」への変化も高い割合を示し, 「田」,「その他の農地」からの変化が多かった。

次に, 1970 年頃から 2000 年頃では, 全体の $35.0 \%$ （海を除く）のメッシュで卓越土地利用が 変化している。この 2 時期間での土地利用項目別 変化割合（図6）を見てみると,「その他の農地」 からの変化と「宅地」への変化が高い割合を示し 


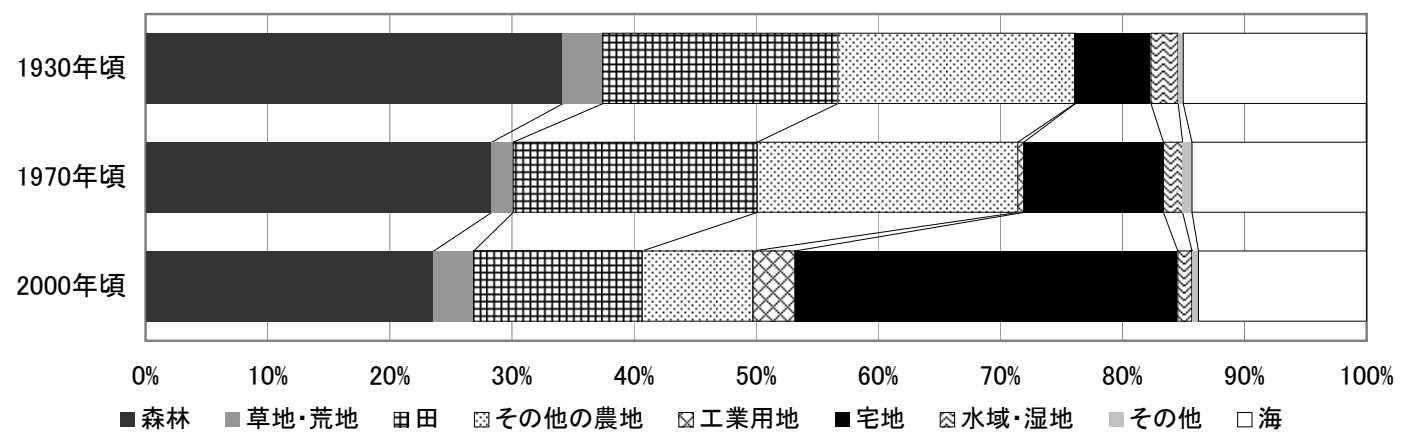

図5 東京圈における 3 時期の土地利用割合

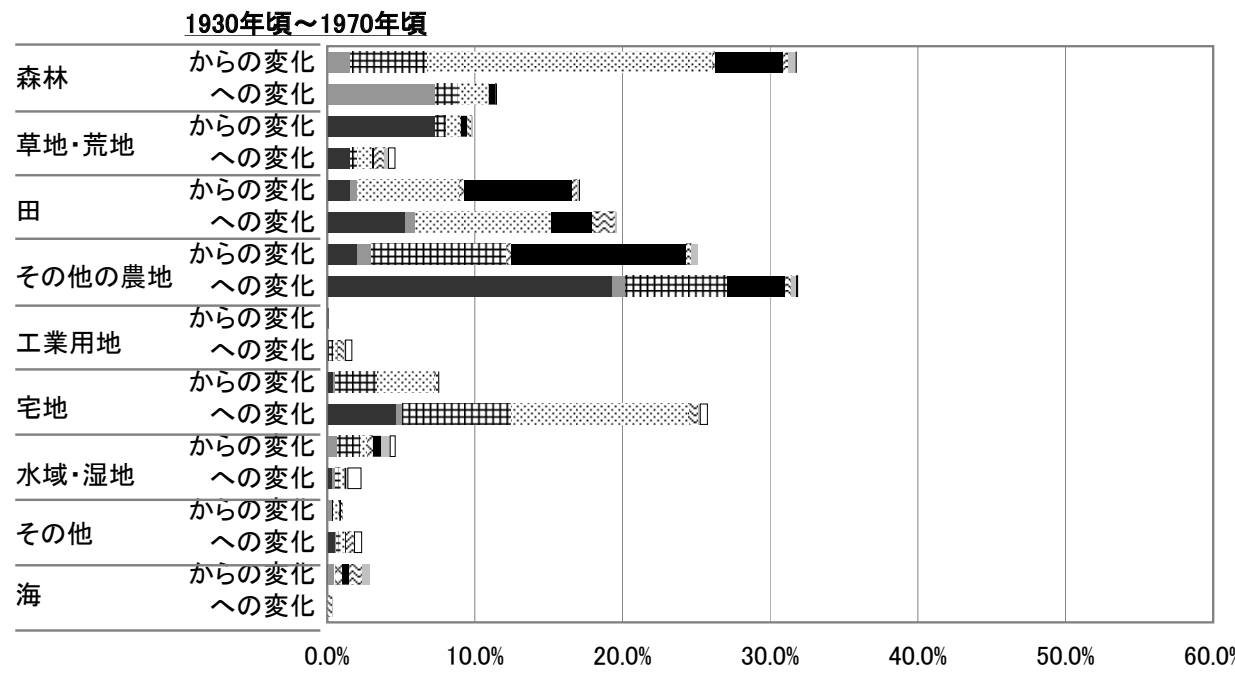

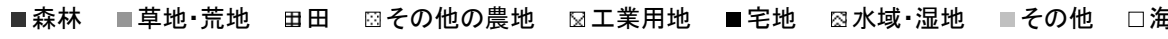

1970年頃 2000年頃

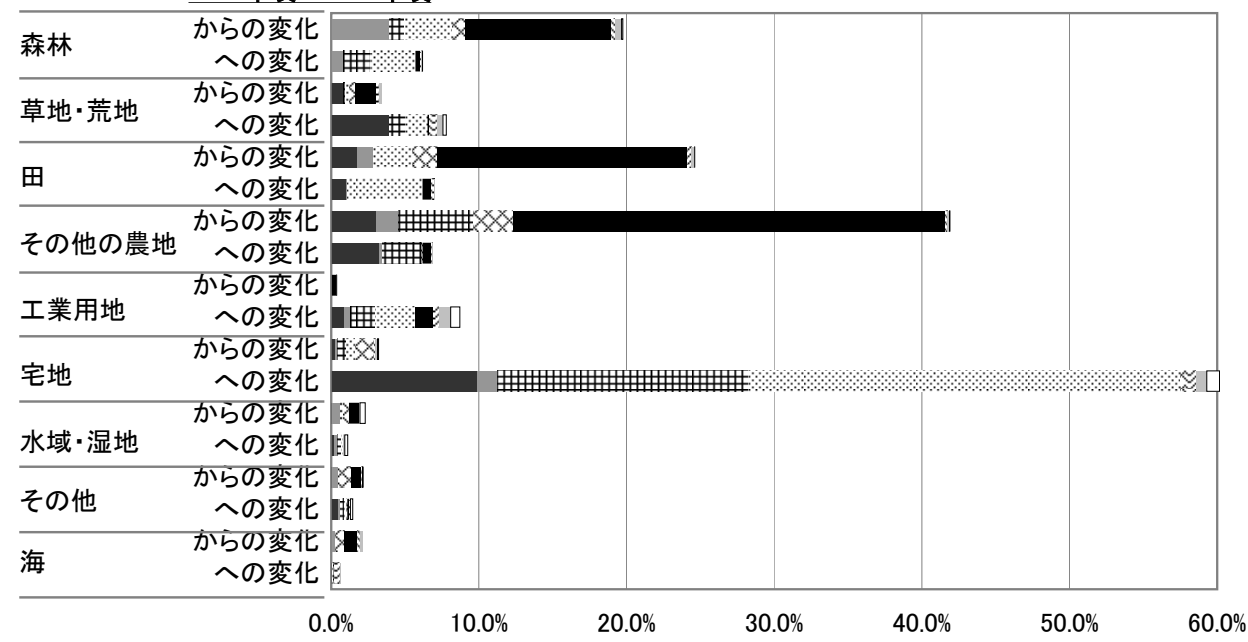

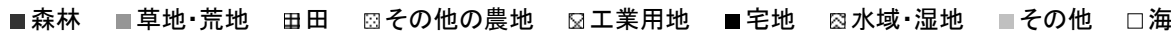

図6 東京圈における土地利用項目別変化割合

各項目の「からの変化」および「への変化」をそれぞれ合算すると100\%になる。 
た。「その他の農地」からの変化の大部分は「宅地」 への変化であった。また，「宅地」は「その他の 農地」以外では「田」からの変化が多かった。

以上を要約すると東京圈では, 札幌圈でみられ たような自然緑地が生産緑地を経て宅地化すると いう2 段階の土地利用変化パターンがより明瞭で あり，具体的には平野部において市街地としての 宅地の周辺に農地が広がり, さらにその周辺に森 林が分布していたところへ，市街地の拡大に伴い 農地がさらに外縁へ遷移していったということで あろう。

\section{3. 大阪圏}

大阪圈の土地利用メッシュマップ (図 7 ) から, 1930 年頃では中央部と北東部に「宅地」が分布
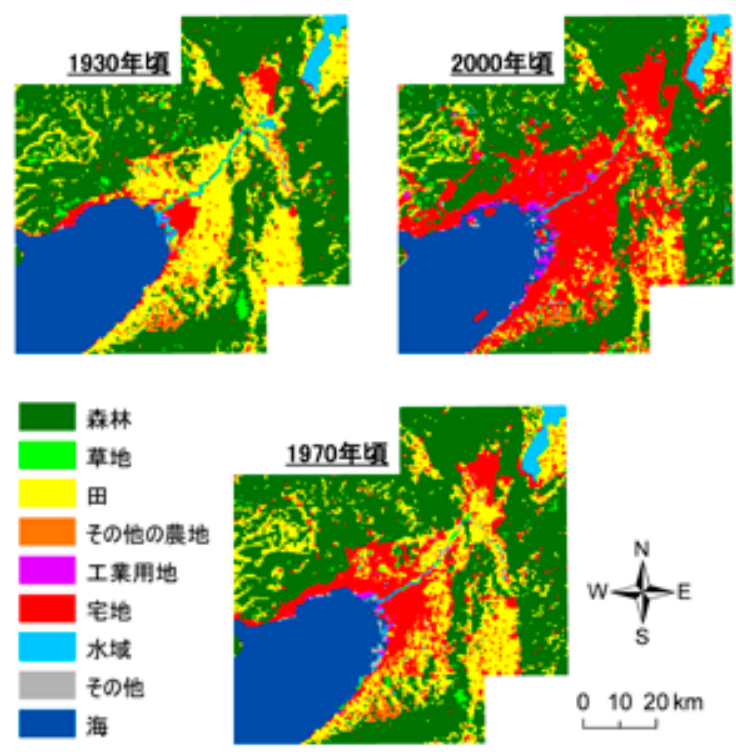

図7 大阪圈の土地利用分布
していることがわかる。さらに，「宅地」の周辺 に「田」が多く分布し，それらを取り囲むように 「森林」が分布している。1970 年頃, 2000 年頃で は「宅地」の周辺の「田」が減少し，「宅地」の 増加がみられた。

大阪圈における 3 時期の土地利用割合（図 8) を見てみると, 「森林」,「田」,「水域・湿地」は 3 時期を通して減少し,「宅地」,「工業用地」は 増加している。「草地・荒地」,「その他の農地」 は 3 時期ともに低い割合であった。

1930 年頃から 1970 年頃にかけては, 全体の $17.8 \%$ (海を除く）のメッシュで卓越土地利用が 変化している。この 2 時期間での土地利用項目別 変化割合（図 9）を見てみると，「田」，「森林」 からの変化と「宅地」への変化が高い割合を示し, 特に「田」から「宅地」への変化が高い割合を占 めた。また,「森林」から「田」への変化も高い 割合を占めた。

次に, 1970 年頃から 2000 年頃にかけては, 全 体の $22.9 \%$ （海を除く）のメッシュで卓越土地利 用が変化している。この 2 時期間での土地利用項 目別変化割合を見てみる（図 9 ) と, 「田」,「森 林」からの变化と「宅地」への変化が高い割合を 示し, 特に「田」から「宅地」への変化が高い割 合を示した。これらは 1930 年頃から 1970 年頃に かけての土地利用変化と同様であるが, さらに高 い割合で変化していた。また,「森林」から「宅地」 への変化も高い割合を示した。

以上を要約すると, 大阪圈は札幌圈, 東京圈と 異なり農地の大半を水田が占め, 畑地はほとんど ないといえる。また,「森林」から「田」を経て「宅地」 になるという2段階変化がみられる一方で, 1930

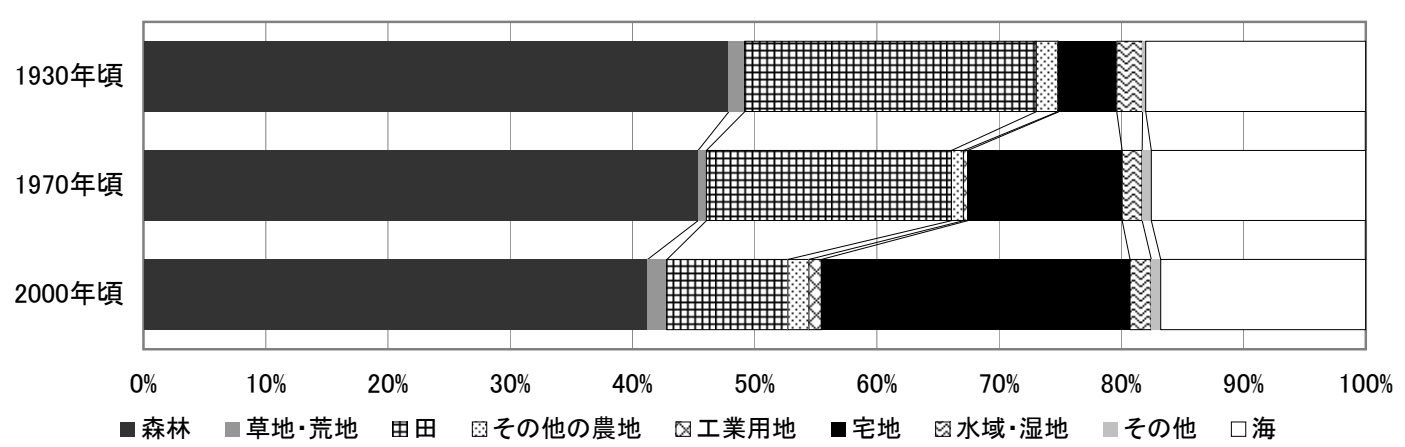

図8 大阪圏における 3 時期の土地利用割合 
1930年頃〜 1970年頃

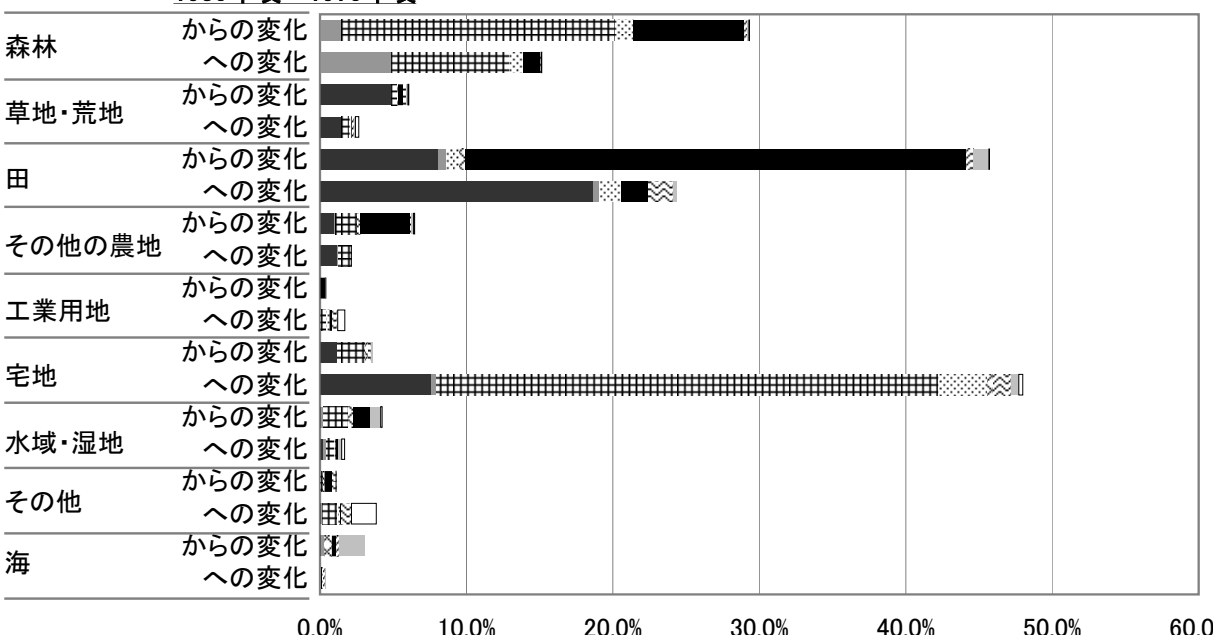

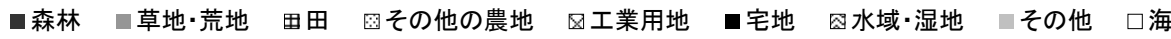

1970年頃〜2000年頃

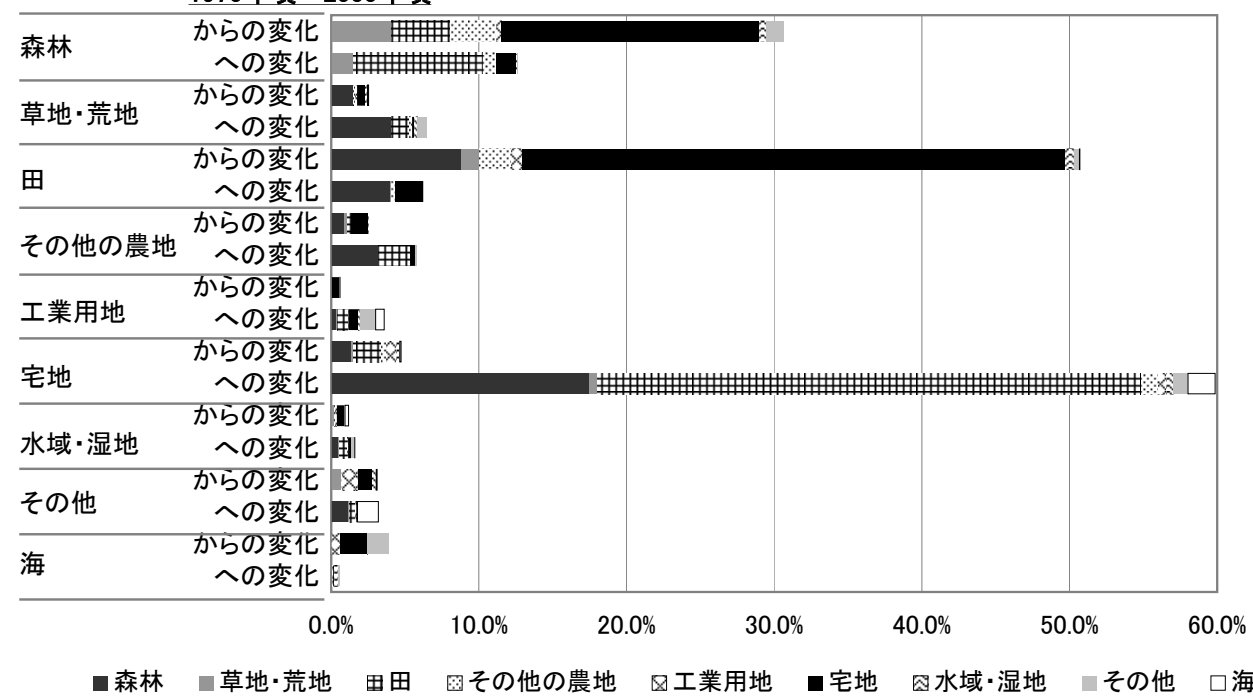

図9 大阪圈における土地利用項目別変化割合

各項目の「からの変化」および「への変化」をそれぞれ合算すると100\%になる。

年頃においてすでに「田」であったところで宅地 化が顕著なこと, 1970 年頃以降,「森林」が直接 宅地化される変化が多くみられることが特徵的で ある。

\section{3都市圏の比較}

時期を経るごとに 3 都市圈ともに「森林」の減 少, 「宅地」の増加がみられた点は共通している。 大阪圈では 3 時期を通して農地の減少がみられた
が，札幌圈・東京圈では 1930 年頃から 1970 年頃 にかけて農地が増加し, 1970 年頃以降減少した。 また，札幌圈は東京圈・大阪圈に比べ「宅地」の 面積が狭い一方，農地の占める割合が高かった。 これらのことから，札幌圈は東京圈，大阪圈に比 べ都市圈が今後も拡大していく可能性が考えられ る。

1930 年頃から 1970 年頃にかけて, 土地利用が 変化している地域の割合は東京圈が最も高く, 次 
が札幌圈で, 大阪圈が最も低い割合であった。こ れは 1970 年頃から 2000 年頃 (札幌圈は 1990 年頃) でも同様であった。

3 時期間の土地利用変化を見てみると,「宅 地」への变化が高い割合を占め, 特に大阪圈で は, 土地利用の変化した地域の $73.5 \%$ が「宅地」 への変化であった。札幌圈では 43.6\%, 東京圈で は $54.3 \%$ であった。「森林」,「草地・荒地」から 「宅地」へ変化している割合は札幌圈, 大阪圈が 同程度で，それぞれ $18.2 \% ， 18.7 \%$ であり，東京 圈は $16.6 \%$ であった。「田」,「その他の農地」か ら「宅地」への変化は東京圈が最も高い割合を示 し, 62.4\%であった。札幌圈, 大阪圈はそれぞれ 55.8\%, 54.2\%であった。さらに, 1930 年頃で「森 林」, 「草地・荒地」, 1970 年頃で「田」,「その他 の農地」そして 2000 年頃で「宅地」へと 2 段階 変化しているメッシュは, 東京圈では 1,640 メッ シュが該当し, これは「宅地」へと変化した地域 の 10.3\%を占める。同様のメッシュは, 札幌圈で は 177 メッシュで $11.2 \%$, 大阪圈では 255 メッシュ で3.7\%を占める。

以上のことから, 土地利用変化パターンからみ たとき， 2 大都市圈としての東京圏と大阪圈は非 常に対照的であり，北海道の札幌圈は，その両都 市圈の特徵を合わせ持つような変化をしてきたこ とが明らかとなった。

\section{IV. 土地利用変化と地形特性との関係}

本章では， 3 都市圈 3 時期の土地利用メッシュ マップ, 標高図, 傾斜図より, 標高, 傾斜別に土 地利用割合および変化割合を算出することで，土 地利用分布やその变化と地形特性との関係を分析 した。

\section{1. 札幌圏}

札幌圈の標高 $20 \mathrm{~m}$ ごと, 傾斜 1 度ごとの土地 利用割合（図 10, 11）を見てみると, 1930 年頃 から 1970 年頃にかけて, 標高 $40 \mathrm{~m}$ 以下, 傾斜 4 度以下の地域で「田」の増加がみられた。一方, 標高 $40 \mathrm{~m}$ 以上, 傾斜 4 度以上の地域では「その 他の農地」の増加がみられた。低標高・緩傾斜地 域では「その他の農地」から「田」へ, 高標高 · 急傾斜地域では「田」から「その他の農地」へと
変化したところが多かった。1930 年頃では「宅地」 の大部分は標高 $0 \sim 60 \mathrm{~m}$, 傾斜 $0 \sim 2$ 度の地域 に分布しているが，1970年頃ではそれ以上の高 標高・急傾斜地域でも「宅地」が増加している。

1970 年頃から 1990 年頃にかけては, 標高 0 〜 $20 \mathrm{~m}$, 傾斜 $0 \sim 1$ 度の低標高・緩傾斜地域で「そ の他の農地」が増加していた。この大部分は「田」 からの変化であった。それ以外の地域では「そ の他の農地」から「宅地」へと高い割合で変化 していた。1990 年頃では標高 $100 \mathrm{~m}$ 以下の地域 の $9.6 \%$, 傾斜 5 度以下の地域の $22.7 \%$ が「宅地」 となっている。

\section{2. 東京圈}

東京圈の標高 $20 \mathrm{~m}$ ごと, 傾斜 1 度ごとの土地 利用割合（図 12, 13）を見てみると, 1930 年頃 から 1970 年頃にかけて, 低標高・緩傾斜地域の「森 林」が減少し，「宅地」へと変化している。「その 他の農地」は標高 $20 \mathrm{~m}$ 以上, 傾斜 6 度以上の地 域で増加がみられ，その大部分は「森林」からの 変化であった。

1970 年頃から 2000 年頃にかけては, 「田」,「そ の他の農地」は大幅に減少し, その大部分は「宅 地」へと土地利用変化しているが, 低標高・緩傾 斜地域の方がより高い割合で変化していた。2000 年頃では標高 $100 \mathrm{~m}$ 以下の地域の $48.5 \%$, 傾斜 5 度以下の地域の $48.0 \%$ が「宅地」である。

\section{3. 大阪圏}

大阪圈の標高 $20 \mathrm{~m}$ ごと, 傾斜 1 度ごとの土地 利用割合（図 14，15）を見てみると，1930年頃 から 1970 年頃にかけて, 標高 $100 \mathrm{~m}$ 以上の地域, 傾斜 7 度以上の地域で「田」の増加がみられた。 この大部分は「森林」からの変化である。また低 標高・緩傾斜地域で「森林」,「田」から「宅地」 へと変化した割合が高かった。

1970 年頃から 2000 年頃にかけても, 低標高・ 緩傾斜地域でさらに高い割合で「宅地」が増加 した。2000 年頃では標高 $100 \mathrm{~m}$ 以下の地域の $64.7 \%$, 傾斜 5 度以下の地域の $62.1 \%$ が「宅地」 である。 
標高: 1930 年頃
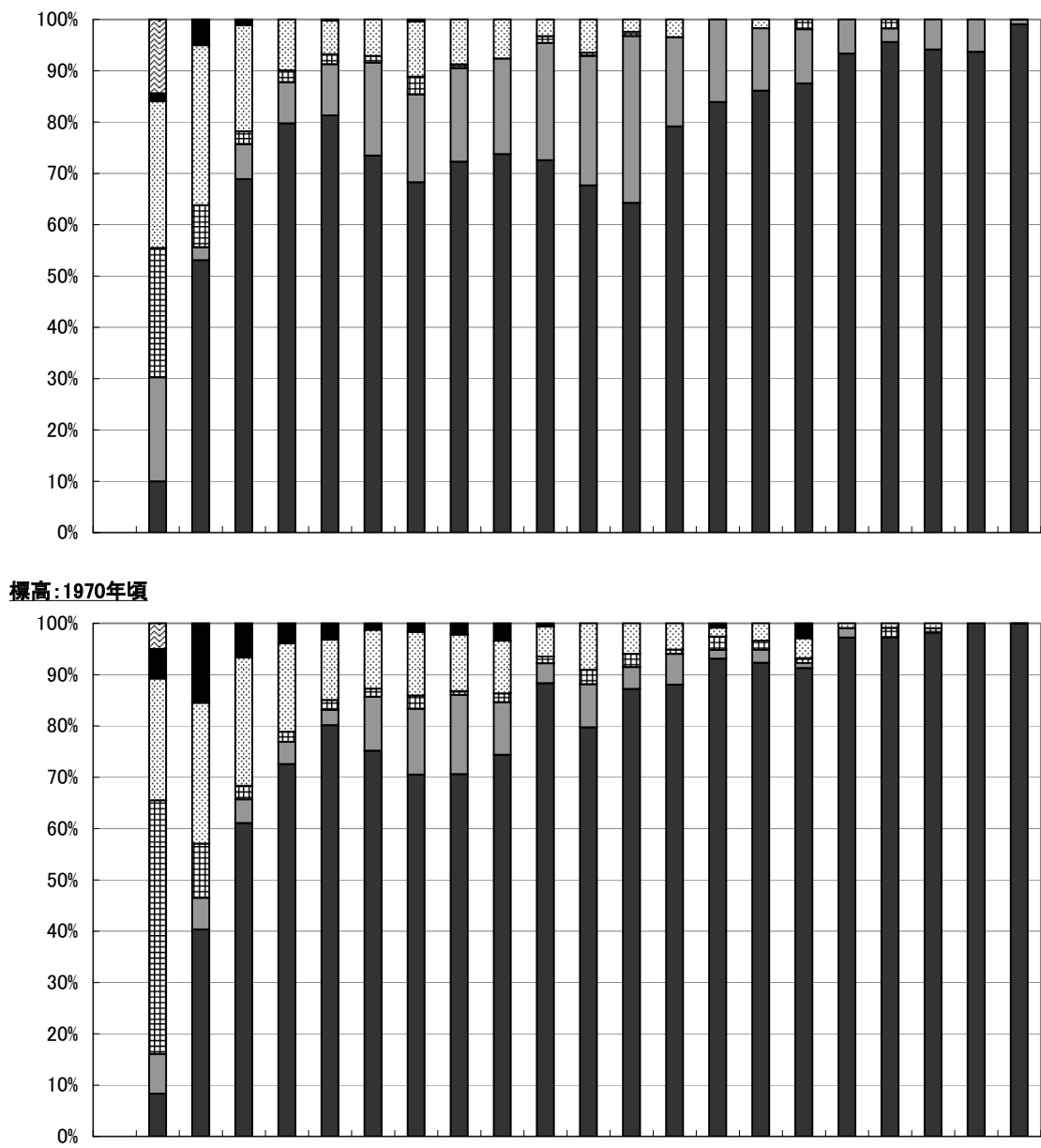

標高: 1990 年頃

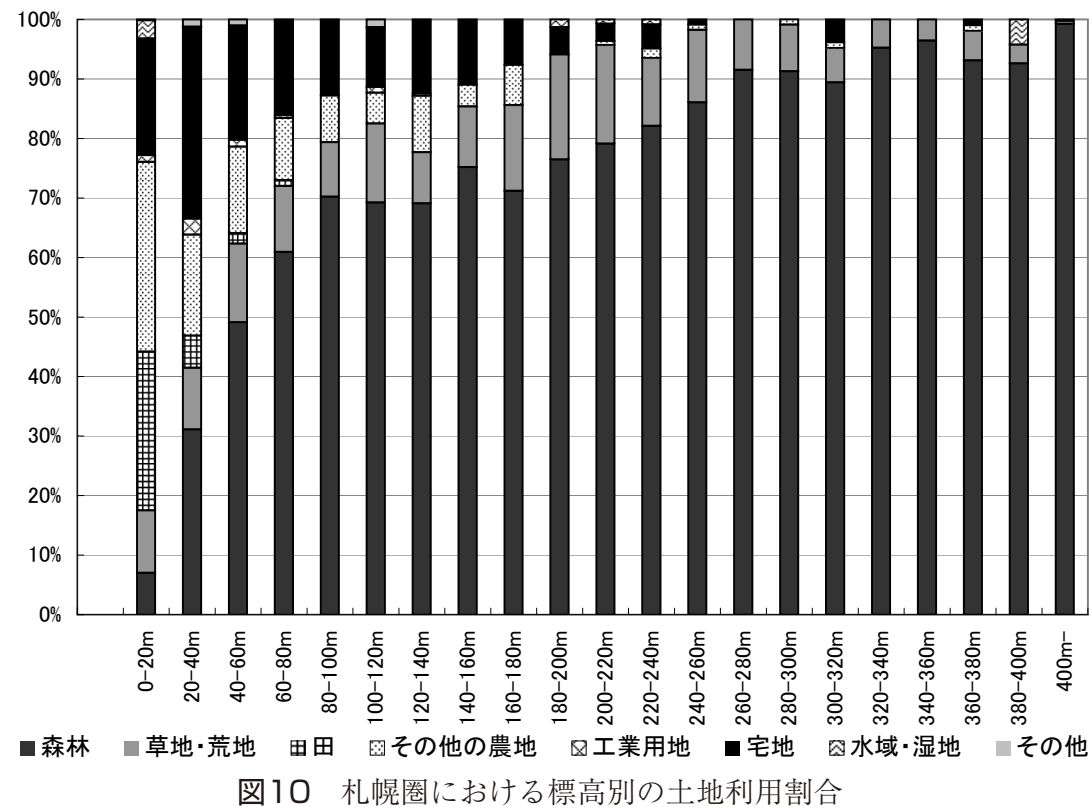




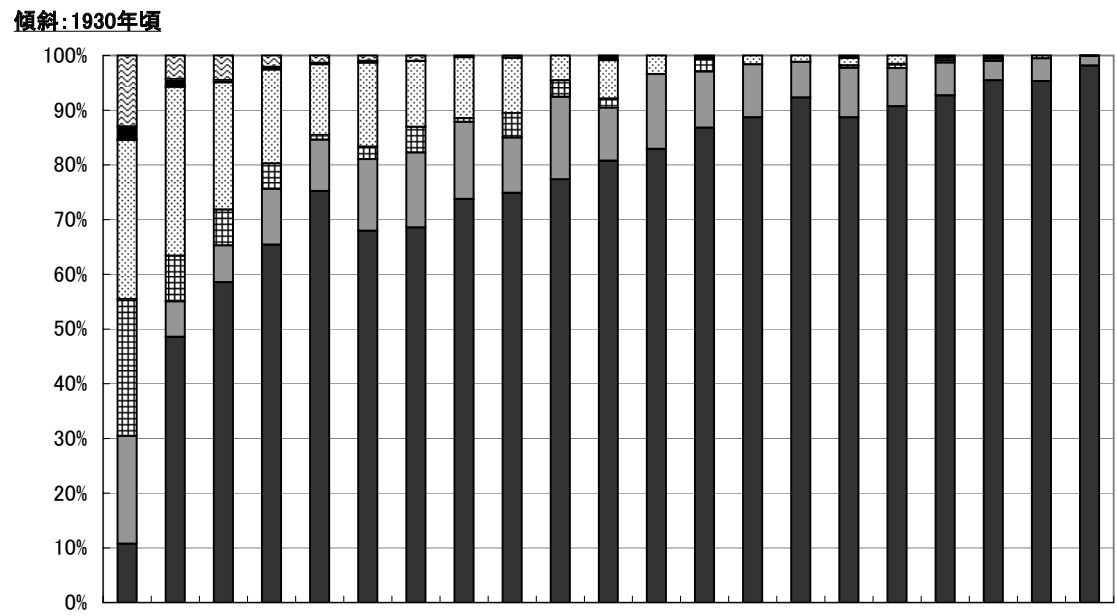

傾斜: 1970 年頃

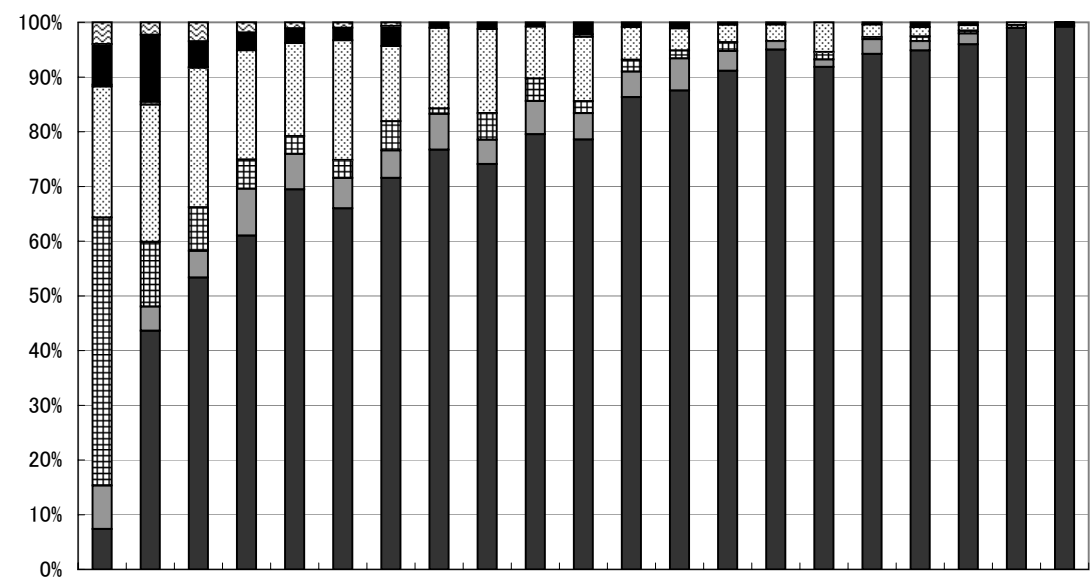

傾斜: 1990 年頃

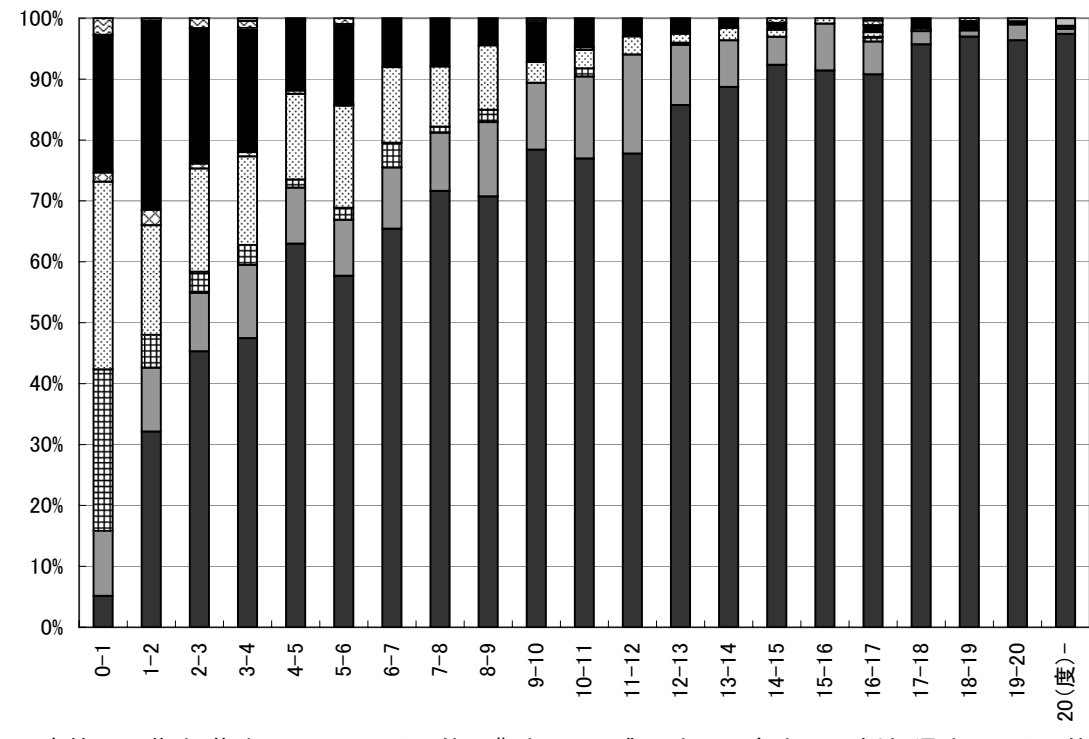

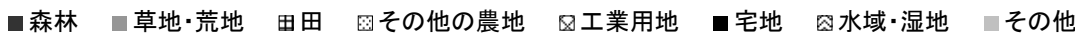

図 11 札幌圈における傾斜別の土地利用割合 

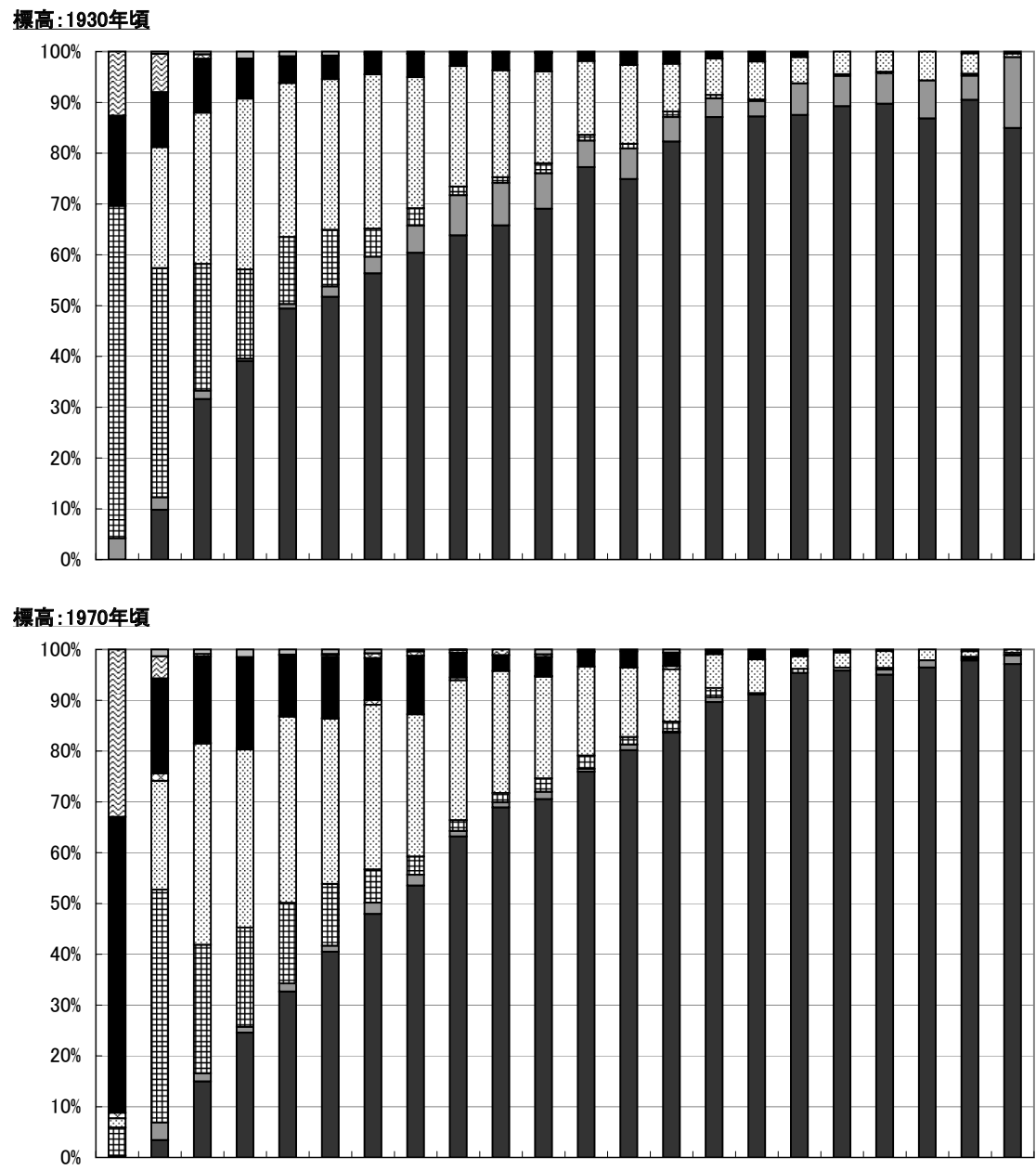

標高: 2000 年頃

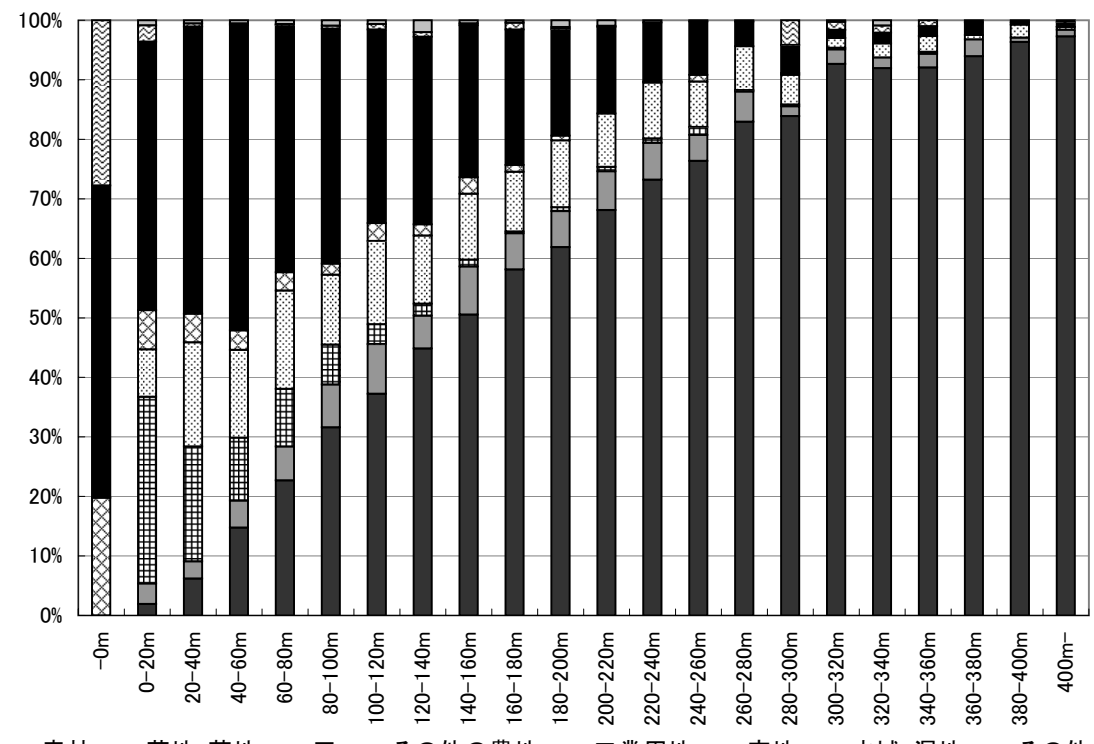

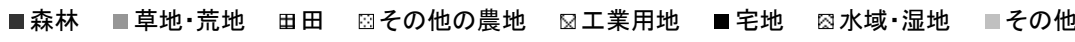
図12 東京圏における標高別の土地利用割合 

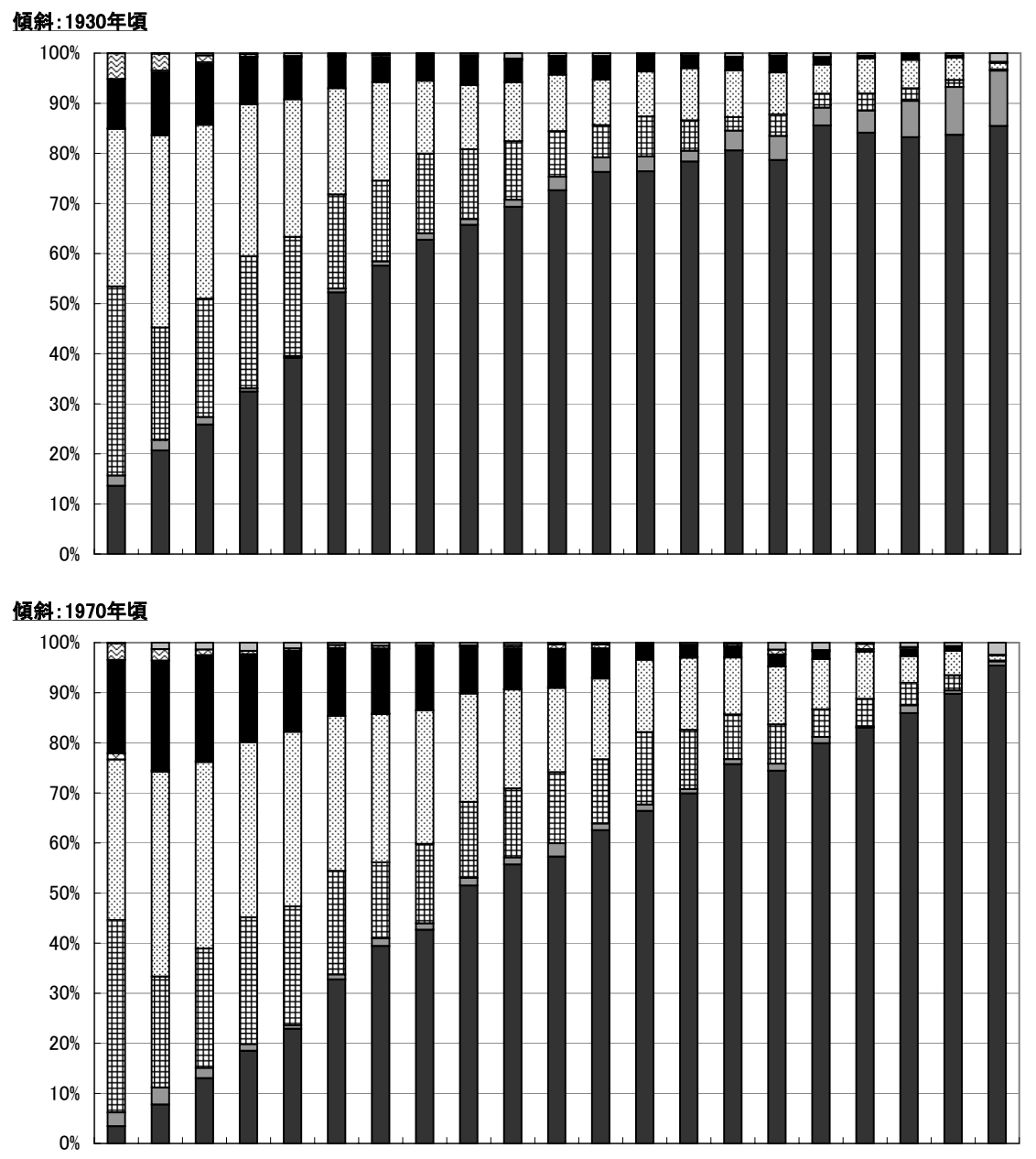

傾斜:2000年頃

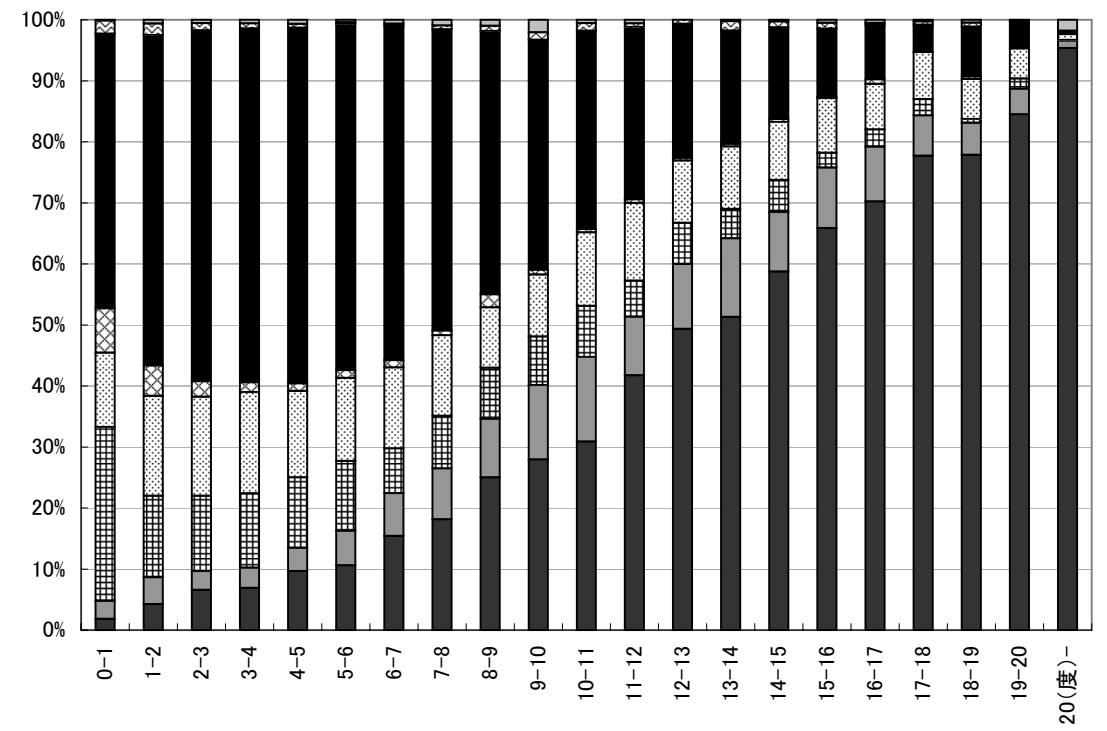

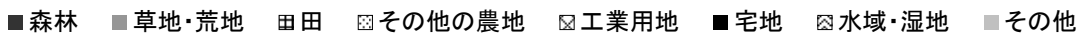
図13 東京圈に打ける傾斜別の土地利用割合 

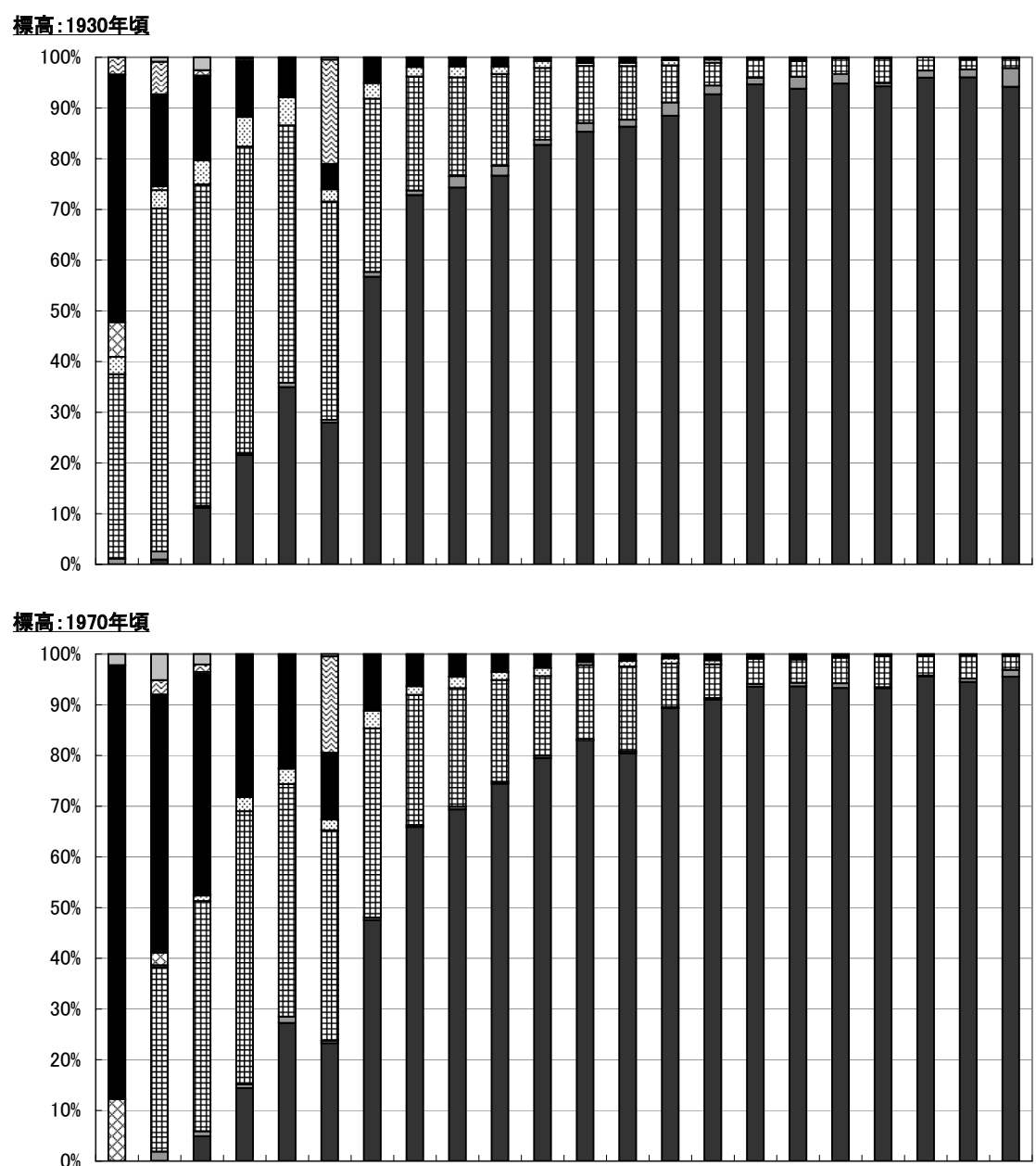

\section{標高: 2000年頃}

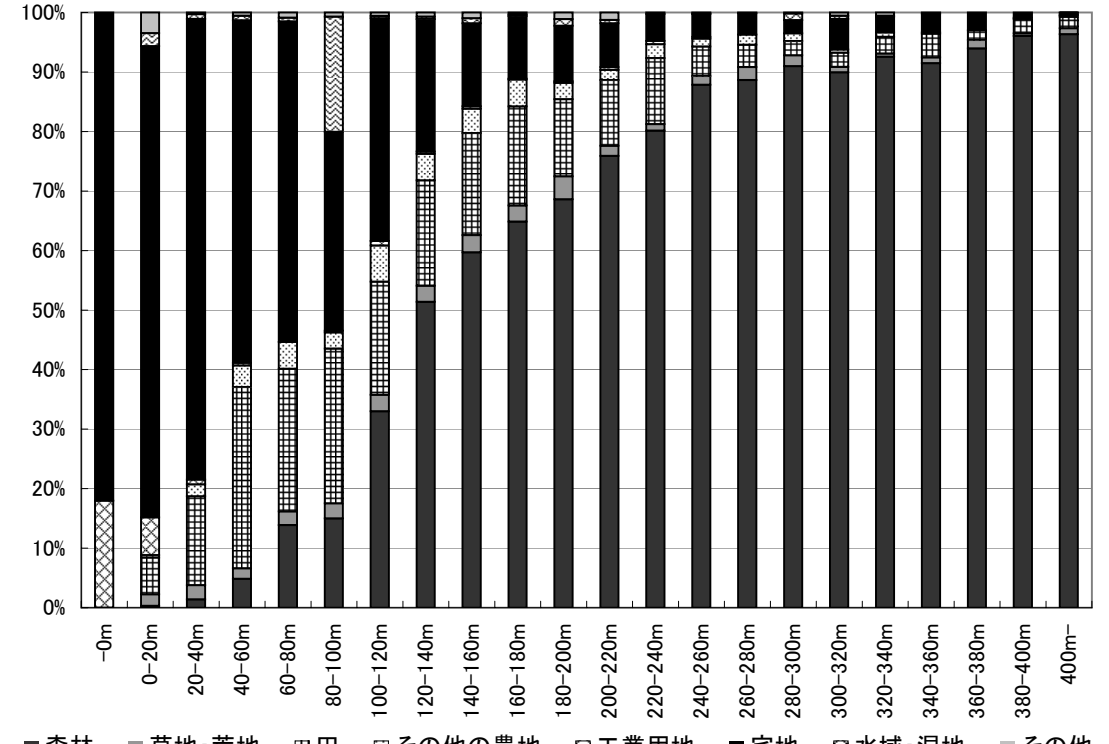

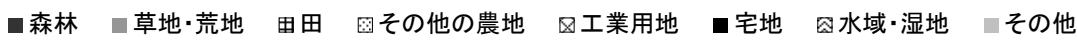
図 14 大阪圈に扔ける標高別の土地利用割合 

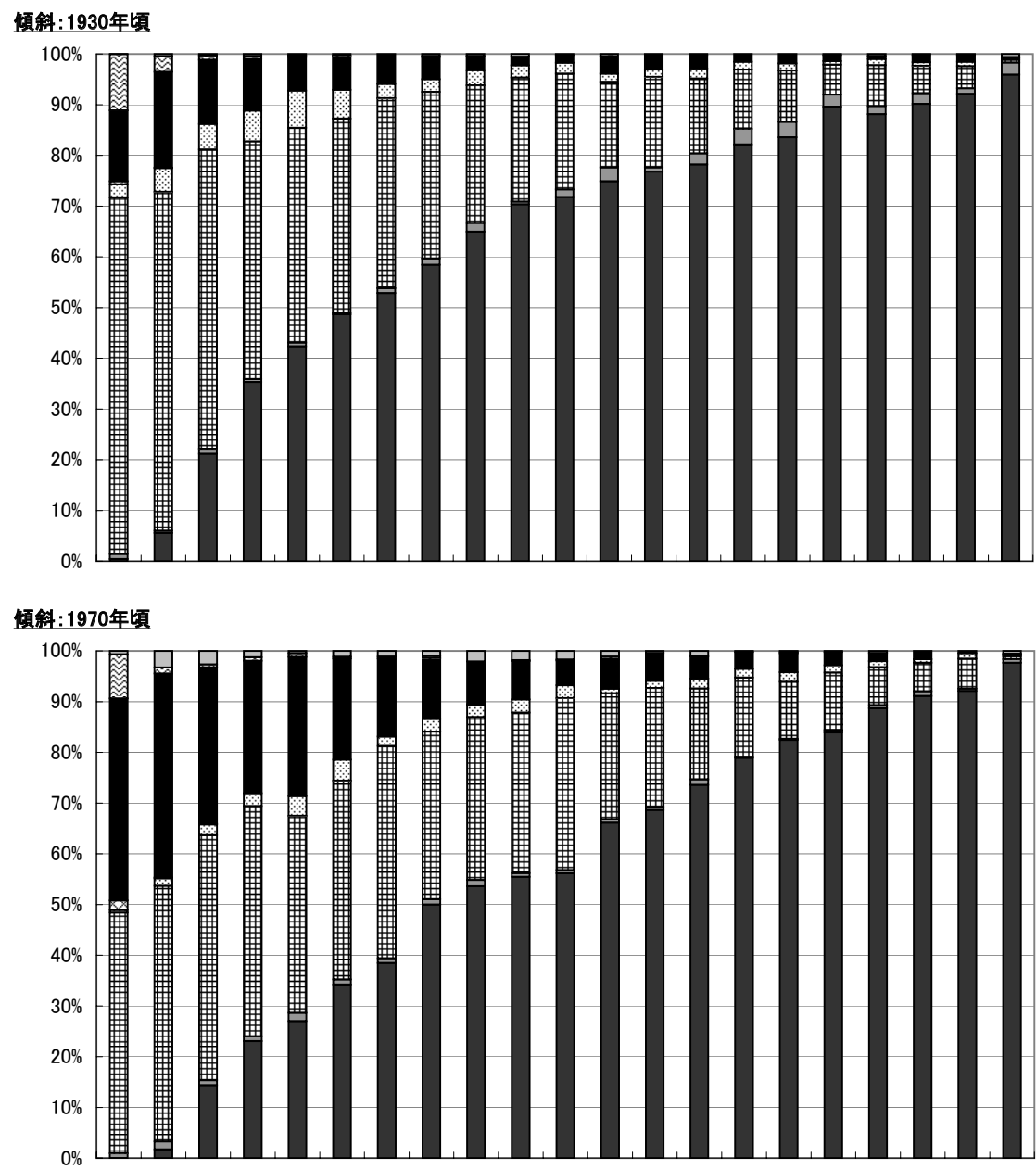

値斜: 2000年頃

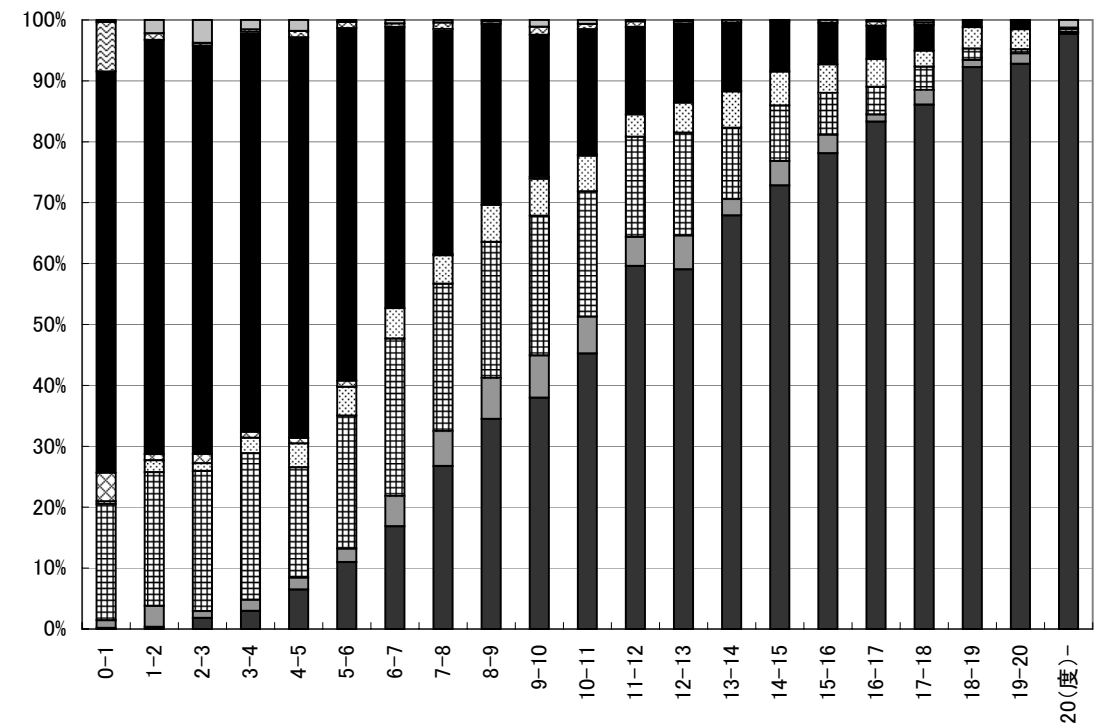

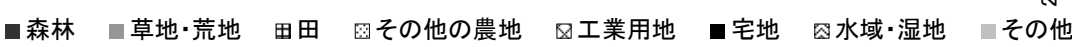

図15大阪圈に扮ける傾斜別の土地利用割合 


\section{3都市圏の比較}

3 都市圈とも時期を経るごとに「宅地」が増加 しているが，その割合は都市圈によって異なって いた。3都市圈の中で, 東京圈が最も「宅地」の 占める割合は高かったが，低標高・緩傾斜地域に 限ると, 大阪圈の方が「宅地」の占める割合は高 かった。これは, 札幌圈, 東京圈と比べて大阪圈 では低標高・緩傾斜地域の面積が狭いなか開発が 進んできたためであると考えられる。

より具体的に土地利用変化と地形特性との関係 を 3 都市圈で比較してみる。3 都市圈において 1930 年頃から 1970 年頃で土地利用が変化した地 域の割合を標高ごとに見てみると，3都市圈とも に低標高地域の方が土地利用変化しやすいという ことがいえる。これは低標高地域の面積が広く， まとまった土地開発が進みやすいことが要因とし て効いているといえる。標高 $40 \mathrm{~m}$ 以下の地域は, 札幌圈で5,381 メッシュ（全体の 44.6\%)，東京 圈で 26,503 メッシュ（全体の $53.4 \%$ ), 大阪圈で 4,727 メッシュ（全体の $20.9 \%$ ）を占める。この 標高帯では大阪圈が最も高い割合で土地利用変化 しているが，これは前述のように相対的に面積が 狭い状況下で開発が進んできたことを示してい る。それ以上の標高では東京圈の方が高い割合で 土地利用変化しており, 大阪圈がそれに次ぐ。こ れには東京圈の標高 $40 \sim 100 \mathrm{~m}$ の面積が相対的 に広いことが関係していると考えられる。札幌圈 は, 全体の変化割合は低いが, 標高 $160 \sim 340 \mathrm{~m}$ の地域では 3 都市圈で最も高い割合を示した。こ の標高帯は札幌市南部の豊平川沿岸の住宅地や温 泉街などが相当する。

1970 年頃から 2000 年頃で土地利用が変化し た地域の割合を標高ごとに見てみると, 1930 年 頃から 1970 年頃と同様に，3都市圈ともに低標 高地域の方が土地利用変化しやすいということ がいえる。そのなかでも標高 $160 \mathrm{~m}$ までは東京 圈が最も高い割合で土地利用変化している。標 高 $160 \mathrm{~m}$ 以下の面積をみると, 札幌圈 7,840 メッ シュ（全体の $65.0 \%$ ), 東京圈 39,095メッシュ (全体の $78.7 \%$ ), 大阪圈 11,946メッシュ（全体 の $52.8 \%$ ）であり, 面積の広狭が土地利用変化に 関係しているといえる。一方, 標高 $160 \sim 240 \mathrm{~m}$ の地域では札幌圈が最も高く, 前述の札幌市南部
の宅地開発がこの時期も継続していることと関連 している。それ以上の標高帯では 3 都市圈ともに 同程度に土地利用変化率が低い。

次に，3都市圈において 1930 年頃から 1970 年 頃で土地利用が変化した地域の割合を傾斜角ごと に見てみると，3都市圈ともに緩傾斜地域の方が 土地利用変化しやすいということがいえる。傾斜 $0 \sim 1$ 度では札幌圈が最も高い割合を示したが, 傾斜 1 度以上の地域では東京圈が最も高い割合で 土地利用変化している。大阪圈がそれに次ぎ, 札 幌圈は傾斜 1 度以上の地域では逆に最も割合が低 かった。

3 都市圈において 1970 年頃から 2000 年頃で土 地利用が変化した地域の割合を傾斜角ごとに見て みると, 1930 年頃から 1970 年頃と同様に, 傾斜 $0 \sim 1$ 度の地域で最も高い割合で土地利用変化し たのは札幌圈であった。一方, 傾斜 1 度以上の地 域では東京圈が最も高い割合を示し, 次いで大阪 圈, 札幌圈であった。札幌圈では傾斜が急な地域 ほど土地利用変化割合が低いという明瞭な相関関 係がみられる一方, 東京圈・大阪圈ではともに, 傾斜 $5 \sim 6$ 度に変化割合が最も高いピークがあ り, それ以下では傾斜が急なほど変化割合が高く, それ以上では傾斜が急なほど変化割合が低い傾向 がみられる。

以上のことから, 札幌圈は広大な平野部を有 し, 低標高・緩傾斜地域に開発適地としての余地 を残しているといえる。東京圈も広大な平野部を 有するものの, 首都圈として早期に開発がはじま り市街地の拡大が著しく, より標高が高く傾斜の 急な地域へ開発が及んでいるといえる。一方, 都 市開発としては東京圈同様に先発地域である大阪 圈は, 平野部の面積も狭いため, より標高が高く 傾斜の急な地域へ開発が及んでいるといえる。

\section{V. おわりに}

本研究では, 札幌 - 東京 · 大阪 3 都市圈の 3 時 期の土地利用メッシュマップを作成することで, 各都市圈の土地利用変化を時空間的に比較分析す ることができた。その結果，2大都市圈としての 東京圈と大阪圈は非常に対照的であり, 北海道の 札幌圈は, その両都市圈の特徵を合わせ持つよう な変化をしてきたことが明らかとなった。 
地形特性は 3 都市圈で異なっていたが, 土地利 用変化と標高や傾斜との間には関係性がみられ, 低標高・緩傾斜地域の方が土地利用変化しやすい ということがわかった。札幌圈では低標高・緩傾 斜地域で「宅地」の占める割合は相対的に低く, 特に東部の低標高・緩傾斜地域で今後宅地化が進 展する可能性が考えられる。東京圈では低標高 · 緩傾斜地域の「宅地」の割合は高かったが, 北部 の低標高・緩傾斜地域では「田」も多く分布して いる。大阪圈では低標高・緩傾斜地域の大部分が 宅地化されている。このように低標高・緩傾斜地 域で「宅地」の占める割合は 3 都市圈で異なって いたが，それは都市化の進展度の違いとともに， その地域の地形特性に影響されていることがわ かった。

今後は地形だけではなく土壤など他の自然的 データや，人口や地価などの社会経済的デー夕を 土地利用メッシュマップと重ね合わせ分析するこ とにより，都市の変遷をより深く分析することが 可能であると考えられる。

\section{謝辞}

本研究を進めるにあたり, 株式会社フォテクの中根貴 雄氏には札幌圈のDEMデータの提供を受け，NPO法人 EnVision 環境保全事務所の阿部やゆみ氏には土地利用 メッシュマップ作成に関する資料提供を受けた。また本研 究は, 総合地球環境学研究所の研究プロジェクト「都市の 地下環境に残る人間活動の影響（プロジェクトリーダー： 谷口真人)」から研究助成を受けた。以上記して謝意を表 する。な打本研究の骨子は, 2010年度東北地理学会・北海 道地理学会秋季学術大会で発表した。

\section{参考文献}

池見洋明・江崎哲郎・ 三谷泰浩・マリサメイリン・石松 裕一郎・松木洋忠 (2008): 過去 100 年間の $100 \mathrm{~m}$ メッシュ 土地利用図作成と GIS 分析. 地理情報システム学会講 演論文集， 17，57-60.

王尾和寿（2008）：流域圈における水系を視点とした景観 特性の分析一那珂川, 霞ヶ浦, 鬼怒川, 小貝川の各流域 を事例として一，地学雑誌，117，534-552.
王尾和寿・桑原祐史・村山祐司（2006）：地形㧍上び河川 からの距離に着目した景観変化の解析. 地理情報システ 厶学会講演論文集， 15，463-466.

金田章裕・石川義孝編（2006）：『日本の地誌 8 近畿圈』 朝倉書店.

小疇 尚・福田正已 ·石城謙吉・酒井 昭 - 佐久間 敏雄 菊地勝弘編（1994）：『日本の自然 地域編 1 北海道』 岩波書店.

杉森啓明・大森博雄（1996）：土地利用デー夕による多摩 川中下流域の景観動態の把握. GIS一理論と応用，4, 51-62.

中村和郎・小池一之・武内和彦編（1994）：『日本の自然 地域編 3 関東』岩波書店.

氷見山幸夫 · 岩上 恵 - 井上笑子 (1991)：明治後期一大 正前期の土地利用の復原. 北海道教育大学大雪山自然教 育研究施設研究報告, 26, 55-63.

水見山幸夫 ·太田伸裕（1993）：大正期～現代の北海道の 土地利用変化. 北海道教育大学大雪山自然教育研究施設 研究報告, 28, 1-13.

水見山幸夫 ·本松宏章 (1994）：明治 · 大正期 現代の東 北地方の土地利用変化. 北海道教育大学大雪山自然教育 研究施設研究報告, 29, 1-16 ,

水見山幸夫 - 綿木尚弘 (1990)：大正期の北海道の土地利 用の復原. 北海道教育大学大雪山自然教育研究施設研究 報告, 25, 25-34.

山下亜紀郎（2004）：日本の主要流域に㧍ける土地利用特 性とその地域差. 地理情報システム学会講演論文集, 13, 79-82

山下亜紀郎・阿部やゆみ・高奥 淳（2008）：アジアのメ ガシテイに扔ける 5 万分の 1 地形図からの土地利用メッ シュマップ作成. 地理情報システム学会講演論文集, 17, 205-208.

山下亜紀郎・阿部やゆみ・高奥 淳 (2009)：東京・大阪 大都市圈に打ける旧版地形図からの土地利用メッシュ マップ作成と土地利用変化の分析. 地理情報システム学 会講演論文集，18，529-534.

Yamashita, A. (2011): Comparative Analysis on Land Use Distributions and Their Changes in Asian Mega Cities. In Taniguchi, M. ed. Groundwater and Subsurface Environments: Human Impacts in Asian Coastal Cities. Springer., $61-81$ 